\title{
Universal Testing Policy for COVID-19 in Pregnancy: A Systematic Review
}

\section{OPEN ACCESS}

Edited by:

Constantinos Tsioutis, European University Cyprus, Cyprus

Reviewed by:

Ruchi Tiwari,

U.P. Pandit Deen Dayal Upadhyaya

Veterinary University, India

Domenico Tortorella,

Icahn School of Medicine at Mount

Sinai, United States

*Correspondence:

Zaleha Abdullah Mahdy zaleha@ppukm.ukm.edu.my

Specialty section:

This article was submitted to Infectious Diseases - Surveillance,

Prevention and Treatment,

a section of the journal

Frontiers in Public Health

Received: 01 September 2020

Accepted: 05 January 2022

Published: 08 February 2022

Citation:

Hashim NAF, Mahdy ZA, Abdul Rahman R, Kalok AHM and Sutan $R$

(2022) Universal Testing Policy for COVID-19 in Pregnancy: A Systematic

Review.

Front. Public Health 10:588269. doi: 10.3389/fpubh.2022.588269

\begin{abstract}
Nur Amirah Farhanah Hashim ", Zaleha Abdullah Mahdy ${ }^{\text {*, }}$ Rahana Abdul Rahman ${ }^{1}$, Aida Hani Mohd Kalok ${ }^{1}$ and Rosnah Sutan ${ }^{2}$

${ }^{1}$ Department of Obstetrics and Gynaecology, Faculty of Medicine, Universiti Kebangsaan Malaysia Medical Centre, Cheras, Malaysia, ${ }^{2}$ Department of Community Health, Faculty of Medicine, Universiti Kebangsaan Malaysia Medical Centre, Cheras, Malaysia
\end{abstract}

Background: The coronavirus disease (COVID-19) has spread at an accelerated rate. WHO reported that in the general population, the majority are either asymptomatic or mildly infected. In view of the high risk of SARS-CoV-2 transmission from a pregnant woman to her newborn, healthcare workers and other patients, it is a raised concern whether universal testing should be implemented in this targeted population. The current guidelines have not recommended a universal testing policy. In certain European countries, however, the policy was implemented by some hospitals in regions with high prevalence of COVID-19 infection.

$\operatorname{Aim}(\mathbf{s})$ : To assess the justification for universal screening of pregnant women for COVID-19 prior to admission in labor through systematic review of antenatal prevalence of asymptomatic infection, hence risk of inadvertent spread of infection.

Materials and Methods: Three databases confined to PubMed, Ovid and Science Direct were used to search for articles from November 2019 onwards published in the English language. The search was conducted using the keywords "COVID-19" or "coronavirus" or "SARS-CoV-2" and "pregnancy" or "pregnant" or "obstetric" or "labor" and "universal" or "testing" or "prevalence". The review was registered with PROSPERO.

Results: The search result retrieved 34 studies, with the majority consisting of retrospective cohort studies, while other studies such as prospective cohort study, research letters and a case series were also identified. A total of 19,958 pregnant women were universally tested until the date of report. Overall, the prevalence of universal testing among pregnant women presenting to labor and delivery units are higher in Western regions. From the total number of pregnant women 5.3\% tested positive and among these, the majority $(75.5 \%)$ did not manifest any symptoms at the time of testing.

Conclusion: In areas with high prevalence of COVID-19 infection, the implementation of a universal testing policy among pregnant women presenting to labor and admission units may be cost effective in helping to curb disease transmission.

Systematic Trial Registration: https://www.crd.york.ac.uk/prospero/display_record .php?ID=CRD42020184248, PROSPERO: CRD42020184248.

Keywords: severe acute respiratory syndrome coronavirus 2, pregnancy, universal testing, prevalence, policy 


\section{INTRODUCTION}

Coronavirus disease (COVID-19), a respiratory illness that is caused by a novel coronavirus (SARS-CoV-2) is a global public health crisis and emergency. Since the World Health Organization (WHO) announced it as a pandemic on 11 March 2020, the virus has continued to spread rapidly and tremendously worldwide (1). As of 6 February 2021, the number of individuals infected globally has reached over 105 million of the population, with more than 2 million deaths ${ }^{1}$. Large studies of five vaccine candidates' efficacy and safety results have been publicly reported through press releases and several countries have begun implementing public vaccination, however it is still too early to perceive widespread benefit ${ }^{2}$, as viral mutations continue to be reported.

A report by the WHO stated that approximately $80 \%$ of the COVID-19 infected population are either asymptomatic or mildly symptomatic (2). Asymptomatic patients are those who have positive test result for SARS-CoV-2 without symptom manifestation. A study by researchers at Johns Hopkins University showed that universal testing increased COVID19 case detection by more than 200 percent in general as compared to targeted testing, and concluded that more testing resources are needed to curb the infection (3). The study also summarized that unrecognized asymptomatic cases can hinder preventive strategies, as well as increase the risk of the virus spreading (3). As pregnant women are also affected by coronavirus, this disease has drawn attention around the world, whether a universal testing policy should be imposed on all pregnant women who attend labor and admission units. In the United States, the National Institutes of Health categorized the disease severity into: asymptomatic, mild, moderate, severe critical illness (4). Knowledge regarding the capability of the virus to spread from an asymptomatic patient is still limited and poorly understood (5). Liu et al. described two out of 15 cases of pregnant women who were asymptomatic at presentation and underwent testing in view of contact history, in whom pneumonic lesion of COVID-19 was identified upon computed tomography evaluation (6). A study in an affiliated pair of New York City hospitals revealed 14 out of 43 (32.6\%) pregnant women who were initially either asymptomatic and presented for obstetrically indicated labor induction, or remained asymptomatic upon presentation, and were subsequently identified to have positive COVID-19 infection upon universal testing at labor unit admission (7). Such asymptomatic pregnant women are at higher risk of infecting their newborns upon birth, healthcare workers and other patients if they are not identified.

According to the WHO, the decision to perform a test should be based on clinical and epidemiological factors that meet the

\footnotetext{
${ }^{1}$ https://www.worldometers.info/coronavirus/ (accessed February 6, 2021). ${ }^{2} \mathrm{https}$ //www.who.int/news-room/q-a-detail/coronavirus-disease-(covid-19)vaccines (accessed February 5, 2021).

Abbreviations: COVID-19, Coronavirus Disease 2019; SARS-CoV-2, Severe Acute Respiratory Syndrome Coronavirus 2; PPE, Personal Protective Equipment; WHO, World Health Organization; CDC, Centers for Disease Control and Prevention; MMAT, Mixed Method Appraisal Tools.
}

suspected case definition for COVID-19 (8). In order for a test to be used for screening procedures in early disease detection, it should fulfill certain criteria such as validity, reliability, yield, cost, acceptance and follow-up services (9). It is more desirable and cost-effective to conduct universal testing in a population where the prevalence is high (10). This review therefore aims to look at reported prevalence rates of COVID-19 and thus explore the need for a universal testing policy for COVID-19 among pregnant women especially at the time of admission for delivery. It should be borne in mind that inadvertent exposure of healthcare workers to undiagnosed COVID-19 positive patients is an occupational hazard that comes with dire consequences, not only on the health and life of the worker, but also on healthcare services as a result of staff shortage due to quarantine and illness. Infection from an asymptomatic pregnant woman with COVID-19 infection who comes in labor in particular is a hazard to the healthcare worker that we should be seriously concerned about.

\section{METHOD}

\section{Study Design}

This is a systematic review of literature that was conducted in accordance with the Preferred Reporting Items for Systematic Reviews and Meta-Analyses (PRISMA) guidelines. The study protocol and review were registered with PROSPERO (CRD42020184248). Two other systematic reviews were registered simultaneously in the same PROSPERO proposal but are dealt with separately.

\section{Literature Search Strategy}

A thorough and comprehensive literature search for studies published from November 2019 onwards was conducted and limited to English language publications. Three different electronic databases (PubMed, Ovid and Science Direct) were searched using the keywords "universal testing," "COVID-19" and "pregnancy." The PICOS terms used are as shown in Table 1. Additional relevant studies found from the references were also retrieved. The Boolean operator 'AND' was used to combine parts of the subject terms and 'OR' was used to expand the search. Only the latest publication would be chosen when there were similar studies with more than one publication.

\section{Screening of Articles for Eligibility and Quality Assessment}

The articles identified from the databases and additional resources were screened for eligibility. First, the title and abstract were screened. Second, eligible studies had to meet all the inclusion criteria developed from the research question using PICOS (Population, Intervention, Comparator, Outcome, Study) design as shown in Table 2. Exclusion criteria includes patients known to have previously been tested positive for SARS-CoV2 infection. Full articles were retrieved and read in the event of any doubt or uncertainty regarding the content relevance during the abstract screening. After a comprehensive list of abstracts was obtained, the articles were retrieved and reviewed in fulltext. One researcher screened all studies and the results were 
collated and reviewed by the second researcher. In the event of disagreement involving the study selection, a third reviewer would be consulted to reach a consensus.

\section{Data Extraction}

The following information was manually extracted from each study: year and country of publication, name of first author, study design, sample size/number of pregnant women who participated, trimester, number of pregnant women with positive or negative COVID-19 infection and number of asymptomatic infected pregnant women. The relevant data extracted was organized into tables using an Excel $^{\circledR}$ spreadsheet. Gray literature was searched for any written policy of universal testing for COVID-19 in pregnancy.

\section{Data Synthesis and Quality Assessment}

Information retrieved was analyzed and interpreted. The primary outcomes assessed were the number of population with positive COVID-19 infection through universal testing, the number of asymptomatic pregnant women, and their prevalence. The information was synthesized using a narrative (descriptive) method. The quality of each study was independently evaluated by the first researcher using the Mixed Methods Appraisal Tools (45).

\section{RESULTS}

The selection process of articles and inclusion in the systematic review was summarized in Figure 1 using the PRISMA flow diagram for systematic review. The initial search yielded a total of 356 articles. Other sources such as references from searched articles yielded three additional articles for this review. After removing the duplicates, 185 articles were screened for keywords relevance from the title and abstract. The full-text versions of the publications were reviewed in case of uncertainty. Only those that fulfill the inclusion criteria shown in Table $\mathbf{1}$ and English publications were included for eligibility assessment. The full texts of these studies were fully examined. Eventually, only a total of 34 articles were included in this review, consisting

TABLE 1 | PICOS criteria for inclusion and exclusion of studies.

\begin{tabular}{|c|c|c|}
\hline Parameter & Inclusion criteria & Data extraction \\
\hline Population & $\begin{array}{l}\text { Pregnant women presented to } \\
\text { labor and delivery admission unit }\end{array}$ & Location \\
\hline Intervention & $\begin{array}{l}\text { Universal testing on all pregnant } \\
\text { women presented to labor and } \\
\text { delivery admission unit }\end{array}$ & $\begin{array}{l}\text { Prevalence of positive test } \\
\text { for COVID-19 }\end{array}$ \\
\hline Comparator & None & \\
\hline Outcome & $\begin{array}{l}\text { Pregnant women with positive } \\
\text { test for COVID-19 }\end{array}$ & $\begin{array}{l}\text { Prevalence of symptomatic } \\
\text { and asymptomatic women } \\
\text { with COVID-19 positive test }\end{array}$ \\
\hline Study & $\begin{array}{l}\text { Case reports/observational } \\
\text { studies }\end{array}$ & Type of study design \\
\hline
\end{tabular}

mainly of retrospective cohort studies, followed by research letter, prospective cohort studies and case series. The data from these 34 studies was further summarized in Table 2. A total of 19,958 pregnant women worldwide were universally tested for COVID19 infection upon arrival at labor and delivery admission units.

\section{Risk of Bias}

By using the Mixed Methods Appraisal Tools (MMAT) (3), the risk of bias of the studies were summarized in Table 2. In general, the individual studies had low to moderate range of risk of bias due to adequate approach to the research question and findings, with presence of coherence among the sources, data collection and analysis. In contrast, research letters and case series had moderate to serious risk of bias due to poor inclusion criteria. However, the clinical cases were presented clearly with clear messages provided.

\section{Main Findings}

This systematic review reports the prevalence of universal testing policy worldwide. It is notably found that the policy is adopted mostly in Western countries, as the implementation of the policy is highest in regions such as New York, Italy, Spain and Portugal. About two thirds $(13,165 / 19,958$ or $66.0 \%)$ of the population tested were from the United States, one of the countries with the highest number of population affected by the disease. From the total number of 19,958 pregnant women tested, an average of $5.3 \%$ were found to be infected. The total positive test rate ranged from 0.4 (12) to $27.0 \%(40)$. We also found that $1.3 \%(260 / 19,958)$ of the total number of pregnant women presenting to labor and admission units were asymptomatic women who tested positive for COVID-19 infection. Out of the total number of positive tests for COVID-19, the proportion of asymptomatic pregnant women $(75.5 \%)$ was markedly higher than symptomatic pregnant women $(24.5 \%)$. Guidelines vary in terms of recommendation for testing for COVID-19 among pregnant women. The ACOG recommends universal testing in areas with high prevalence of the infection (46). The guidelines issued by the Indian Council of Medical Research recommends universal testing of "all pregnant women in/near labor who are hospitalized for delivery" (47). However, other guidelines may not state such a stand clearly (48), and may rely on clinical screening as first line (49).

\section{DISCUSSION}

This systematic review reports with great concern that the prevalence of asymptomatic COVID-19 patients is threefold that of symptomatic patients, thus seriously raising the question of universal testing, particularly in pregnancy, where there is prolonged close contact with multiple healthcare workers especially when the patient is in labor. Although prevalence varies across the globe and several vaccines have been successfully tested and now implemented, mutants of SARS-CoV-2 appear every so often, hence other preventive measures such as limiting contact and physical distancing still matters.

It is good to note some move toward advocating universal testing of pregnant women attending labor and delivery units, given the recent spike in the prevalence of asymptomatic 
TABLE 2 | Summary of studies reviewing the outcome of universal testing and the prevalence of asymptomatic pregnant women with positive SARS-CoV-2.

\begin{tabular}{|c|c|c|c|c|c|c|c|c|c|c|}
\hline \multirow[t]{3}{*}{ No } & \multirow[t]{3}{*}{ First Author } & \multirow[t]{3}{*}{ Country } & \multirow[t]{3}{*}{ Title } & \multirow{3}{*}{$\begin{array}{l}\text { Universally tested } \\
\text { pregnant women } \\
\boldsymbol{N}\end{array}$} & \multicolumn{4}{|c|}{ CovID-19 Infection } & \multirow[t]{3}{*}{ Study design } & \multirow[t]{3}{*}{ RoB } \\
\hline & & & & & \multirow{2}{*}{$\begin{array}{l}\text { Negative } \\
n(\%)\end{array}$} & \multicolumn{3}{|c|}{ Positive } & & \\
\hline & & & & & & $\begin{array}{l}\text { Total } \\
n(\%)\end{array}$ & $\begin{array}{c}\text { Asymptomatic } \\
n(\%)\end{array}$ & $\begin{array}{c}\text { Symptomatic } \\
n(\%)\end{array}$ & & \\
\hline 1 & Prabhu et al. (11) & $\begin{array}{l}\text { United States } \\
\text { (New York) }\end{array}$ & $\begin{array}{l}\text { Pregnancy and postpartum outcomes in a } \\
\text { universally tested population for SARS-CoV-2 } \\
\text { in New York City: a prospective cohort study }\end{array}$ & 675 & $605(89.6)$ & $70(10.4)$ & $55(78.6)$ & $15(21.4)$ & $\begin{array}{l}\text { Prospective } \\
\text { cohort }\end{array}$ & ++ \\
\hline 2 & Fassett et al. (12) & $\begin{array}{l}\text { United States (Los } \\
\text { Angeles) }\end{array}$ & $\begin{array}{l}\text { Universal SARS-CoV-2 screening in women } \\
\text { admitted for delivery in a large managed care } \\
\text { organization }\end{array}$ & 3,923 & 3,906 (99.6) & $17(0.4)$ & $17(100.0)$ & $0(0.0)$ & $\begin{array}{l}\text { Retrospective } \\
\text { cohort }\end{array}$ & + \\
\hline 3 & $\begin{array}{l}\text { Vintzileos et al. } \\
\text { (13) }\end{array}$ & $\begin{array}{l}\text { United States } \\
\text { (New York) }\end{array}$ & $\begin{array}{l}\text { Screening all pregnant women admitted to } \\
\text { labor and delivery for the virus responsible for } \\
\text { coronavirus disease } 2019\end{array}$ & 161 & $129(81.1)$ & $32(19.9)$ & $21(65.6)$ & $11(34.4)$ & $\begin{array}{l}\text { Retrospective } \\
\text { cohort }\end{array}$ & ++ \\
\hline 4 & $\begin{array}{l}\text { Campbell et al. } \\
\text { (14) }\end{array}$ & $\begin{array}{l}\text { United States } \\
\text { (New York) }\end{array}$ & $\begin{array}{l}\text { Prevalence of SARS-CoV-2 among patients } \\
\text { admitted for childbirth in Southern Connecticut }\end{array}$ & 770 & $740(96.1)$ & $30(3.9)$ & $22(73.3)$ & $8(26.7)$ & $\begin{array}{l}\text { Retrospective } \\
\text { cohort }\end{array}$ & + \\
\hline 5 & $\begin{array}{l}\text { LaCourse et al. } \\
\text { (15) }\end{array}$ & $\begin{array}{l}\text { United States } \\
\text { (Washington) }\end{array}$ & $\begin{array}{l}\text { Low prevalence of SARS-CoV-2 among } \\
\text { pregnant and postpartum patients with } \\
\text { universal screening in Seattle, Washington }\end{array}$ & $188^{\mathrm{a}}$ & $182(97.3)$ & $5(2.7)$ & $1(20.0)$ & $4(80.0)$ & $\begin{array}{l}\text { Retrospective } \\
\text { cohort }\end{array}$ & ++ \\
\hline 6 & Miller et al. (16) & $\begin{array}{l}\text { United States } \\
\text { (Chicago) }\end{array}$ & $\begin{array}{l}\text { Clinical implications of universal severe acute } \\
\text { respiratory syndrome coronavirus } 2 \\
\text { (SARS-CoV-2) testing in pregnancy }\end{array}$ & 635 & $612(96.4)$ & $23(3.6)$ & $10(43.5)$ & $13(56.5)$ & Research letter & ++ \\
\hline 7 & London et al. (17) & $\begin{array}{l}\text { United States } \\
\text { (New York) }\end{array}$ & $\begin{array}{l}\text { The relationship between status at presentation } \\
\text { and outcomes among pregnant women with } \\
\text { COVID-19 }\end{array}$ & 75 & $65(86.7)$ & $10(13.3)$ & $10(100.0)$ & $0(0.0)$ & $\begin{array}{l}\text { Retrospective } \\
\text { cohort }\end{array}$ & ++ \\
\hline 8 & Goldfarb et al. (18) & $\begin{array}{l}\text { United States } \\
\text { (Boston) }\end{array}$ & $\begin{array}{l}\text { Universal SARS-CoV-2 testing on admission to } \\
\text { the labor and delivery unit: low prevalence } \\
\text { among asymptomatic obstetric patients }\end{array}$ & 757 & 737 (97.4) & $20(2.6)$ & $9(45.0)$ & $11(55.0)$ & $\begin{array}{l}\text { Retrospective } \\
\text { cohort }\end{array}$ & + \\
\hline 9 & Ochiai et al. (19) & Japan & $\begin{array}{l}\text { Universal screening for SARS-CoV-2 in } \\
\text { asymptomatic obstetric patients in Tokyo, } \\
\text { Japan }\end{array}$ & 52 & $49(94.2)$ & $3(5.8)$ & $3(100.0)$ & $0(0.0)$ & $\begin{array}{l}\text { Retrospective } \\
\text { cohort }\end{array}$ & ++ \\
\hline 10 & Bianco et al. (20) & $\begin{array}{l}\text { United States } \\
\text { (New York) }\end{array}$ & $\begin{array}{l}\text { Testing of patients and support persons for } \\
\text { coronavirus disease } 2019 \text { (COVID-19) infection } \\
\text { before scheduled deliveries }\end{array}$ & 155 & $131(84.5)$ & $24(15.5)$ & $24(100.0)$ & $0(0.0)$ & $\begin{array}{l}\text { Retrospective } \\
\text { cohort }\end{array}$ & ++ \\
\hline 11 & Ferrazzi et al. (21) & Italy & $\begin{array}{l}\text { SARS-CoV-2 infection testing at delivery: a } \\
\text { clinical and epidemiological priority }\end{array}$ & 1,566 & $1,517(96.9)$ & $49(3.1)$ & $27(55.1)$ & $22(44.9)$ & $\begin{array}{l}\text { Retrospective } \\
\text { cohort }\end{array}$ & + \\
\hline 12 & Herraiz et al. (22) & Spain (Madrid) & $\begin{array}{l}\text { Universal screening for SARS-CoV-2 before } \\
\text { labor admission during COVID-19 pandemic in } \\
\text { Madrid }\end{array}$ & $203^{a}$ & $199(99.0)$ & $2(1.0)$ & $1(50.0)$ & $1(50.0)$ & $\begin{array}{l}\text { Retrospective } \\
\text { cohort }\end{array}$ & ++ \\
\hline 13 & Sutton et al. (23) & $\begin{array}{l}\text { United States } \\
\text { (New York) }\end{array}$ & $\begin{array}{l}\text { Universal screening for SARS-CoV-2 in women } \\
\text { admitted for delivery }\end{array}$ & $215^{\mathrm{a}}$ & $181(84.7)$ & $33(15.3)$ & $29(87.9)$ & $4(12.1)$ & Research letter & +++ \\
\hline
\end{tabular}


14 Gagliardi et al. (24) Italy (Tuscany and Universal severe acute respiratory syndrome

$$
\text { Liguria) }
$$

15 Yassa et al. (25) Turkey admitted for delvery in 2 talin regons

15 Yassa et al. (25) Turkey_outcomes of universal SARS-CoV-2 testing program in pregnant women admitted to

hospital and the adjuvant role of lung

ultrasound in screening: a prospective cohort study

16 Berkowitz et al. United States (26) (Ohio)

Implementation of universal testing for

SARS-CoV-2 in pregnant women with intended admission for delivery

17 Santos et al. (27) Portugal

Prevalence of SARS-CoV-2 infection in asymptomatic pregnant women and their partners in a tertiary care hospital in Portugal

18 Abeysuriya et al. United Kingdom

19 Buckley et al. (29) United States (New York)

Universal screening for SARS-CoV-2 in pregnant women at term admitted to an East London maternity unit

Universal testing of patients and their support persons for severe acute respiratory syndrome coronavirus 2 when presenting for admission to labor and delivery at Mount Sinai Health System

20 Doria et al. (30) Portugal COVID-19 during pregnancy: a case series from an universally tested population from the north of Portuga

21 Bender et al. (31) United States Universal testing for severe acute respiratory (Pennsylvania) syndrome coronavirus 2 in 2 Philadelphia hospitals: carrier prevalence and symptom development over 2 weeks

22 Vinuela et al. (32) Spain (Madrid) SARS-CoV-2 screening of asymptomatic (2020)

women admitted for delivery must be

performed with a combination of

microbiological techniques: an observational study

23 Tanacan et al. (33) Turkey (Ankara) The rate of SARS-CoV-2 positivity in asymptomatic pregnant women admitted to hospital for delivery: experience of a pandemic center in Turkey
428

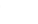

$273(92.2)$

$23(7.8)$

$482(98.1)$

426 (99.5)

$2(0.5)$

$171(96.1)$

$7(3.9)$

$257(83.7)$

50 (16.3)

$91(88.4)$

$12(11.6)$

$310(97.5)$

$8(2.5)$

$91(91.0)$

$9(9.0)$

$9(100.0)$

$203(98.5)$

$(85.7)$

Positive

$\begin{array}{ccc} & \text { Asymptomatic } & \text { Symptomatic } \\ (\%) & n(\%) & n(\%)\end{array}$

2 (66.7) 1 (33.3)

Research letter

$11(47.8)$

Retrospective ++ cohort

(30.0) Research letter $\quad+++$

(0.0) Research letter $\quad+++$

$(100.0)$

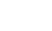

cohor

cohort

$50(100.0)$

$1(8.3)$

Case series

$+++$

Retrospective +++ cohort

Retrospective +++ cohort

Prospective $\quad+++$ cohort 
28 Mei-Dan et al. (38) Canada (Toronto) Questionn Questionnaire-based vs universal PCR testing
for SARS-CoV-2 in women admitted for delivery

29 Maru et al. (39) United States Universal screening for SARS-CoV-2 infection among pregnant women at Elmhurst Hospital Center, Queens, New York

30 Hcini et al. (40) French Guiana Maternal, fetal and neonatal outcomes of large series of SARS-CoV-2 positive pregnancies in peripartum period: a single-center prospective comparative study

31 Figueiredo et al. Portugal (Porto) Systematic screening for SARS-CoV-2 in (41) pregnant women admitted for delivery in a Portuguese maternity

32 Waghmare et al. India Universal screening identifies asymptomatic (42) (Maharashtra) carriers of SARS-CoV-2 among pregnant women in India

33 Diaz-Corvillon Chile Routine screening for SARS CoV-2 in et al. (43)

34 Blitz et al. (44) United States unselected pregnant women at delivery Universal testing for coronavirus 2019 in pregnant women admitted for delivery: prevalence of peripartum infection and rate of asymptomatic carriers at four New York hospitals within an integrated healthcare system

Positive

Negative $n(\%)$

\begin{tabular}{|c|c|c|c|c|c|c|}
\hline & & & & \\
\hline & & $\begin{array}{l}\text { Total } \\
n(\%)\end{array}$ & $\begin{array}{c}\text { Asymptomatic } \\
n(\%)\end{array}$ & $\begin{array}{c}\text { Symptomatic } \\
n(\%)\end{array}$ & & \\
\hline 266 & $260(97.7)$ & $6(2.3)$ & $4(66.7)$ & $2(33.3)$ & $\begin{array}{l}\text { Retrospective } \\
\text { cohort }\end{array}$ & ++ \\
\hline 2,945 & 2,852 (96.8) & $93(3.2)$ & $80(86.0)$ & $13(14.0)$ & $\begin{array}{l}\text { Prospective } \\
\text { cohort }\end{array}$ & + \\
\hline 935 & 858 (91.8) & $77(8.2)$ & $66(85.7)$ & $11(14.3)$ & $\begin{array}{l}\text { Retrospective } \\
\text { cohort }\end{array}$ & ++ \\
\hline 82 & 81 (98.8) & $1(1.2)$ & Ol (0.0) & $1(100.0)$ & $\begin{array}{l}\text { Prospective } \\
\text { cohort }\end{array}$ & ++ \\
\hline 446 & 442 (99.1) & $4(0.9)$ & $3(66.7)$ & $1(33.3)$ & $\begin{array}{l}\text { Prospective } \\
\text { cohort }\end{array}$ & + \\
\hline 124 & 78 (62.9) & $46(37.1)$ & $33(71.7)$ & 13 (28.3) & $\begin{array}{l}\text { Retrospective } \\
\text { cohort }\end{array}$ & ++ \\
\hline 507 & $370(73.0)$ & $137(27.0)$ & $103(75.2)$ & $34(24.8)$ & $\begin{array}{l}\text { Prospective } \\
\text { cohort }\end{array}$ & + \\
\hline 184 & 173 (99.9) & $11(0.1)$ & $9(81.8)$ & $2(18.2)$ & $\begin{array}{l}\text { Prospective } \\
\text { cohort }\end{array}$ & + \\
\hline 1,140 & 999 (87.6) & $141(12.4)$ & $284(73.8)$ & 37 (26.2) & $\begin{array}{l}\text { Prospective } \\
\text { cohort }\end{array}$ & ++ \\
\hline 583 & $546(93.7)$ & $37(6.3)$ & $16(43.2)$ & $21(56.8)$ & $\begin{array}{l}\text { Prospective } \\
\text { cohort }\end{array}$ & + \\
\hline 382 & 318 (83.3) & $64(16.7)$ & 45 (70.3) & 19 (29.7) & $\begin{array}{l}\text { Retrospective } \\
\text { cohort }\end{array}$ & ++ \\
\hline
\end{tabular}

TOTAL

$N$, Pregnant women who were universally tested; $a$, Asymptomatic and inconclusive $(n=1)$; $b$, Results were not obtained within clinically relevant time frame ( $n=26) ; c$, Two women ( $n=2)$ excluded as one was previously suspected and other one declined testing: RoB, Risk of bias; +, Low risk of bias: ++ , Medium risk of bias: +++ , Serious risk of bias. 


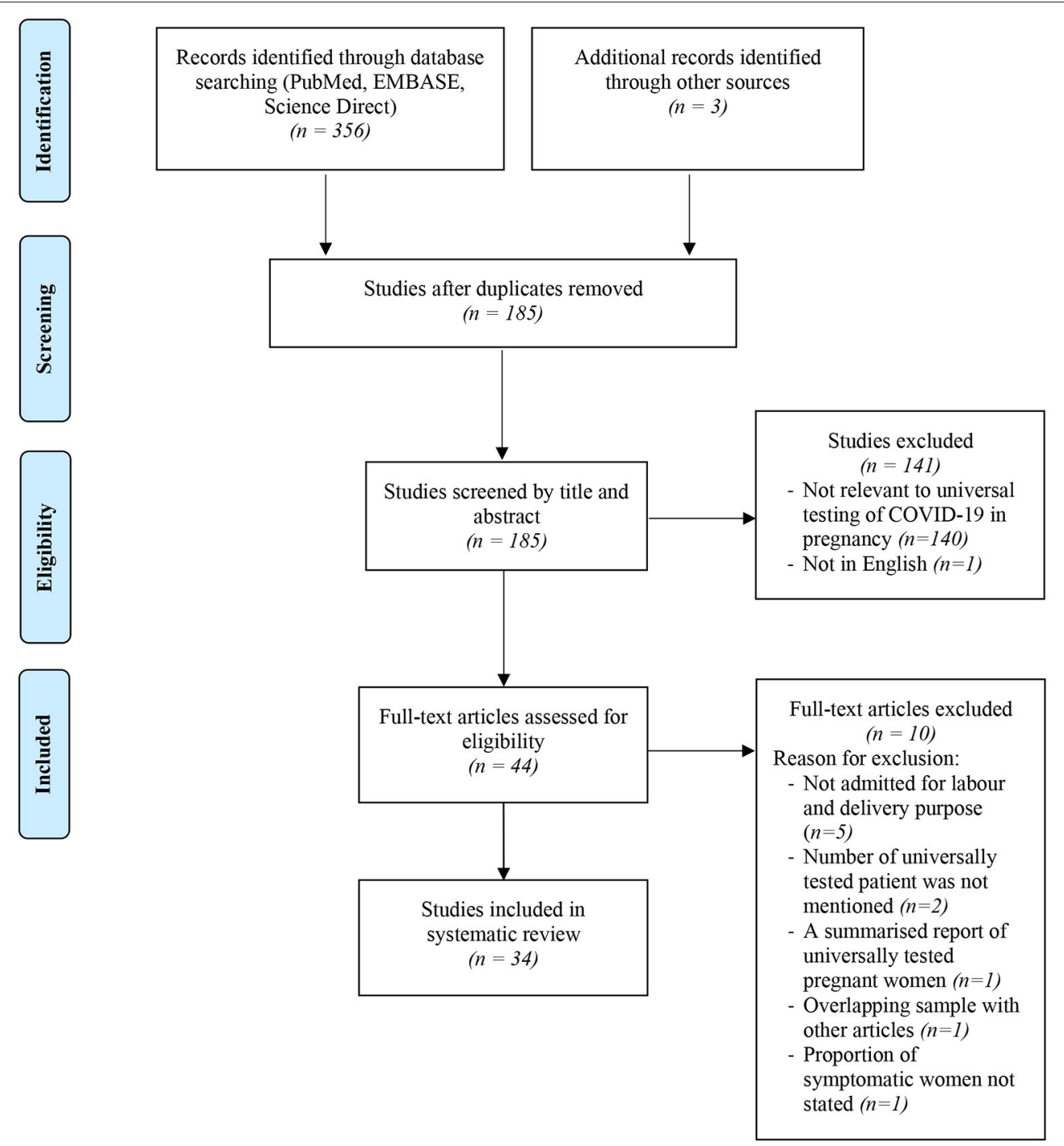

FIGURE 1 | Flowchart showing inclusion in systematic review of studies reporting on prevalence of universal testing policy for COVID-19 in pregnant women.

COVID-19 cases worldwide. Recently, the American College of Obstetricians and Gynecologists published an update on the recommendation to consider universal testing for pregnant women especially in high prevalence areas (46). In a study by Bianco et al., universal screening using the telephone as a screening tool is inadequate as 24 patients who were previously not identified as likely to be COVID-19 positive via such screening, were tested positive from the universal testing (20). Therefore, the findings of this systematic review implies that healthcare workers and other patients are at significant risk of exposure and getting infected with COVID-19, if universal testing of pregnant women is not implemented in high prevalence areas. The alternative measure is universal precaution i.e., wearing of personal protective equipment (PPE) when handling all cases. However, universal usage of PPE will result in wastage of a precious commodity that has been in short supply.
Routine SARS-CoV-2 testing would require the use PPE. On the other hand, in the case of patients with reported symptoms but received negative results, PPE use could be avoided. In general, universal testing may result in an overall increase in terms of PPE usage. Therefore, given the potential increased need for supply, the implementation of universal testing could pose a challenge to the current hospital supply systems. An increased demand for PPE would occur and facilities with limited access to PPE would suffer greatly.

The implementation of universal testing in pregnancy, however, can act as a multipronged approach to reduce the risk of SARS-CoV-2 transmission, particularly in healthcare facilities in regions with high prevalence of the infection. In view of longer exposure between pregnant women and healthcare professionals before, during and after delivery, universal testing in this specific population can assist in infection control operations. It can help protect the safety of newborns, hospital staff, and other patients. 
In addition, it also allows priority clinical care to be given to both the infected mother and her baby at the time of birth and during the postpartum period, in terms of appropriate further treatment such as management of delivery, counseling for breastfeeding and newborn skin-to-skin contact. It is important to bear in mind that the COVID-19 prevalence rate is extremely fluid and has a tendency to escalate rapidly ${ }^{2}$, hence policies and guidelines should be formulated in a flexible manner so as to be enable prompt response with day to day changes in the situation.

Attempts have also been made to elucidate clinical or simple laboratory predictive risk factors for COVID-19 infection among pregnant women in order to proceed to conduct targeted antigen testing (50-52). This may be more feasible options in the long term, especially from the health economics point of view. It can also be implemented irrespective of the local prevalence of the disease.

The prevalence rate from universal testing appears to mirror the rate within the local general population (37). The current compiled review is useful in planning preventive strategies in the interest of the health of pregnant mothers, their babies, and mitigating the risk of healthcare workers. In regions with low COVID-19 prevalence, the approach may be different. The research question on universal testing needs to be addressed carefully. The incubation period for COVID-19 is reported to be between 5 and 14 days and the duration of immunity is still being studied. For populations with low prevalence, using a screening checklist and restricting diagnostic testing only for those with positive screening may be a more cost-effective option. A cost-effectiveness study on universal testing is in order before universal testing can be recommended as a policy. The issue of timing of testing in relation to pregnancy and labor also needs to be considered and are not easy decision points.

\section{Strength and Limitations}

The strength of our study is as a systematic review that looks at universal testing policy for COVID-19 in pregnancy at the point of admission for labor and delivery. It is useful in guiding policy making in relation to preventive measures and testing for the infection. One limitation of this review is the nature of the studies retrieved. Although the majority of studies included are retrospective cohort studies, case reports and research letters that were retrieved are expected to have high risk of bias. Apart from that, we did not report the prevalence of COVID-19 in the general population in individual studies as they were likely to be underreported to various degrees, depending on the extent of mass testing in a particular population. As a result, we were not able to compare the prevalence of infected cases by different regions and countries. It is quite difficult to do this retrospectively for all locations as the local prevalence changes fairly rapidly and the studies were time-sensitive, several of them limiting the study period to 1 or 2 weeks only.

\section{CONCLUSION}

This review looks at the outcome of a universal testing policy in terms of prevalence of asymptomatic pregnant women in various populations. Given the high rate of asymptomatic pregnant women in certain regions of the world, universal testing may provide enhanced safety to the public and healthcare workers in these areas, but cost will be increased from various angles. Although the current trend of universal testing predominates only in developed countries, more studies involving developing and less developed countries should be conducted to provide valuable information of the need for such a policy of universal testing for COVID-19 in pregnancy. Universal testing provides benefits in areas with high prevalence of disease, hence testing for the background prevalence in representative samples of pregnant women in various regions should be considered in order to guide policy making. Above all, in areas with high prevalence of COVID-19, the strategy of universal testing of pregnant women before admitting them for delivery is essential and must be implemented rigorously in order to protect the women, their newborns, and in-contact healthcare workers so as to curb the spread of infection in the community.

\section{AUTHOR CONTRIBUTIONS}

$\mathrm{NAFH}$ led the data synthesis, collection and analysis, while being supervised by ZAM. RS gave an expert clinical advice on methodology and community health, while AHMK and RAR gave expert clinical advice on obstetrics. All authors critically revised the manuscript for important intellectual content and reviewed and approved the final version.

\section{ACKNOWLEDGMENTS}

The authors gratefully acknowledge the support from UKM Faculty of Medicine for NAFH's short term employment as a Research Assistant.

\section{REFERENCES}

1. Li Q, Guan X, Wu P, Wang X, Zhou L, Tong Y, et al. Early transmission dynamics in Wuhan, China, of novel coronavirus-infected pneumonia. N Engl J Med. (2020) 382:1199-207. doi: 10.1056/NEJMoa2001316

2. World Health Organization. WHO Coronavirus Disease (2019). (COVID-19) Situation Report 46. (2019). Available online at: https://www.who.int/docs/ default-source/coronaviruse/situation-reports/20200306-sitrep-46-covid19.pdf?sfvrsn=96b04adf_4 (accessed July 24, 2020).

3. John Hopkins Medicine. COVID-19 Story Tip: Universal Testing May Help Reduce COVID-19 Infections, Deaths in Long-Term Care Facilities. Available

online at: https://www.hopkinsmedicine.org/news/newsroom/news-releases/ covid-19-story-tip-universal-testing-may-help-reduce-covid-19-infectionsdeaths-in-long-term-care-facilities (assessed July 24, 2020).

4. National Institute of Health COVID-19 Treatment Guidelines. Available online at: https://covid19treatmentguidelines.nih.gov/overview/management-ofcovid-19/ (accessed June 22, 2020).

5. Long Q, Tang X, Shi, Q, Li Q, Deng HJ, Yuan J, et al. Clinical and immunological assessment of asymptomatic SARS-CoV-2 infections. Nat Med. (2020) 26:1200-4. doi: 10.1038/s41591-020-0965-6

6. Liu D, Li L, Wu X, Zheng D, Wang J, Yang L, et al. Pregnancy and perinatal outcomes of women with coronavirus disease (COVID-19) 
pneumonia: a preliminary analysis. AJR Am J Roentgenol. (2020) 215:12732. doi: 10.2214/AJR.20.23072

7. Breslin N, Baptiste C, Gyamfi-Bannerman C, Miller R, Martinez R, Bernstein $\mathrm{K}$, et al. Coronavirus disease 2019 infection among asymptomatic and symptomatic pregnant women: two weeks of confirmed presentations to an affiliated pair of New York City hospitals. Am J Obstet Gynecol MFM. (2020) 2:100118. doi: 10.1016/j.ajogmf.2020.100118

8. World Health Organization. Laboratory Testing for Coronavirus Disease (COVID-19) in Suspected Human Cases: Interim Guidance, 19 March 2020. World Health Organization. (2020) Available online at: https://apps.who.int/ iris/handle/10665/331501 (accessed July 20, 2020).

9. Wilson JMG, Jungner G. Principles and Practice of Screening for Disease. Geneva: WHO (1968). Available online at: http://whqlibdoc.who.int/php/ WHO_PHP_34.pdf (accessed July 24, 2020).

10. Maxim LD, Niebo R, Utell MJ. Screening tests: a review with examples. Inhal Toxicol. (2014) 26:811-28 doi: 10.3109/08958378.2014.9 55932

11. Prabhu M, Cagino K, Matthews KC, Friedlander RL, Glynn SM, Kubiak JM, et al. Pregnancy and postpartum outcomes in a universally tested population for SARS-CoV-2 in New York City: a prospective cohort study. BJOG. (2020) 127:1548-56. doi: 10.1111/1471-0528.16403

12. Fassett MJ, Lurvey LD, Yasumura L, Nguyen M, Colli JJ, Volodarskiy M et al. Universal SARS-Cov-2 screening in women admitted for delivery in a large managed care organization. Am J Perinatol. (2020) 37:11104. doi: $10.1055 / \mathrm{s}-0040-1714060$

13. Vintzileos WS, Muscat J, Hoffmann E, John NS, Vertichio R, Vintzileos AM, et al. Screening all pregnant women admitted to labor and delivery for the virus responsible for coronavirus disease 2019. Am J Obstet Gynecol. (2020) 223:284-6. doi: 10.1016/j.ajog.2020.04.024

14. Campbell KH, Tornatore JM, Lawrence KE, lluzzi JL, Sussman LS, et al. Prevalence of SARS-CoV-2 among patients admitted for childbirth in southern connecticut. JAMA. (2020) 323:2520-2. doi: 10.1001/jama.2020.8904

15. LaCourse SM, Kachikis A, Blain M, Simmons LE, Mays JA, Pattison AD, et al. Low prevalence of SARS-CoV-2 among pregnant and postpartum patients with universal screening in Seattle, Washington. Clin Infect Dis. (2020) 72:869-72. doi: 10.1093/cid/ciaa675

16. Miller ES, Grobman WA, Sakowicz A, Rosati J, Peaceman AM. clinical implications of universal severe acute respiratory syndrome coronavirus 2 (SARS-CoV-2) testing in pregnancy. Obstet Gynecol. (2020) 136:2324. doi: 10.1097/AOG.0000000000003983

17. London V, McLaren R Jr, Atallah F, Cepeda C, McCalla S, Fisher N, et al. The relationship between status at presentation and outcomes among pregnant women with COVID-19. Am J Perinatol. (2020) 37:9914. doi: $10.1055 / \mathrm{s}-0040-1712164$

18. Goldfarb IT, Diouf K, Barth WH, Robinson JN, Katz D, Gregory KE, et al. Universal SARS-CoV-2 testing on admission to the labor and delivery unit: low prevalence among asymptomatic obstetric patients. Infect Control Hosp Epidemiol. (2020):41:1095-6. doi: 10.1017/ice.2020.255

19. Ochiai D, Kasuga Y, Iida M, Ikenoue S, Tanaka M. Universal screening for SARS-CoV-2 in asymptomatic obstetric patients in Tokyo Japan. Int $J$ Gynaecol Obstet. (2020) 150:268-9. doi: 10.1002/ijgo.13252

20. Bianco A, Buckley AB, Overbey J, Smilen S, Wagner B, Dinglas C, et al. Testing of patients and support persons for coronavirus disease (2019). (COVID-19) infection before scheduled deliveries. Obstet Gynecol. (2020) 136:283-7. doi: 10.1097/AOG.0000000000003985

21. Ferrazzi E, Beretta P, Bianchi S, Cetin I, Guarnerio P, Locatelli A, et al. SARS$\mathrm{CoV}-2$ infection testing at delivery: a clinical and epidemiological priority. J Matern Fetal Neonatal Med. (2020). doi: 10.1080/14767058.2020.1788532. [Epub ahead of print].

22. Herraiz I, Folgueira D, Villalaín C, Forcén L, Delgado R, Galindo A. Universal screening for SARS-CoV-2 before labor admission during COVID-19 pandemic in Madrid. J Perinat Med. (2020) 48:981-4. doi: 10.1515/jpm-2020-0236

23. Sutton D, Fuchs K, D’Alton M, Goffman D. Universal screening for SARSCoV-2 in women admitted for delivery. N Engl J Med. (2020) 382:21634. doi: 10.1056/NEJMc2009316

24. Gagliardi L, Danieli R, Suriano G, Vaccaro A, Tripodi G, Rusconi F, et al. Universal severe acute respiratory syndrome coronavirus 2 testing of pregnant women admitted for delivery in 2 Italian regions. Am J Obstet Gynecol. (2020) 223:291-2. doi: 10.1016/j.ajog.2020.05.017

25. Yassa M, Yirmibes C, Cavusoglu G, Eksi H, Dogu C, Usta C, et al. Outcomes of universal SARS-CoV-2 testing program in pregnant women admitted to hospital and the adjuvant role of lung ultrasound in screening: a prospective cohort study. J Matern Fetal Neonatal Med. (2020) 33:38206. doi: 10.1080/14767058.2020.1798398

26. Berkowitz KM, Goje O, Eaton J. Implementation of universal testing for SARS-CoV-2 in pregnant women with intended admission for delivery. Am J Obstet Gynecol. (2020) 223:782-3. doi: 10.1016/j.ajog.2020.07.011

27. Santos RR, Martins I, Ayres-de-Campos D. Prevalence of SARS-CoV2 infection in asymtomatic pregnant women and their partners in a tertiary care hospital in Portugal. J Matern Fetal Neonatal Med. (2020). doi: 10.1080/14767058.2020.1793323. [Epub ahead of print].

28. Abeysuriya S, Wasif S, Counihan C, Shah N, Iliodromiti S, Cutino-Moguel MT, et al. Universal screening for SARS-CoV-2 in pregnant women at term admitted to an East London maternity unit. Eur J Obstet Gynecol Reprod Biol. (2020) 252:444-6. doi: 10.1016/j.ejogrb.2020.07.035

29. Buckley A, Bianco A, Stone J. Universal testing of patients and their support persons for severe acute respiratory syndrome coronavirus 2 when presenting for admission to labor and delivery at Mount Sinai Health System. Am J Obstet Gynecol MFM. (2020) 2:100147. doi: 10.1016/j.ajogmf.2020.100147

30. Dória M, Peixinho C, Laranjo M, Mesquita Varejão A, Silva PT. Covid-19 during pregnancy: a case series from an universally tested population from the north of Portugal. Eur J Obstet Gynecol Reprod Biol. (2020) 250:2612. doi: 10.1016/j.jogrb.2020.05.029

31. Bender WR, Hirshberg A, Coutifaris P, Acker AL, Srinivas SK. Universal testing for severe acute respiratory syndrome coronavirus 2 in 2 Philadelphia hospitals: carrier prevalence and symptom development over 2 weeks. Am J Obstet Gynecol MFM. (2020) 2:100226. doi: 10.1016/j.ajogmf.2020.100226

32. Vinuela MC, De León-Luis JA, Alonso R, Catalán P, Lizarraga S, Muñoz $P$, et al. obstetrics and gynecology and microbiology-ID COVID-19 study group. SARS-CoV-2 screening of asymptomatic women admitted for delivery must be performed with a combination of microbiological techniques: an observational study. Rev Esp Quimioter. (2020) 33:41521. doi: $10.37201 / \mathrm{req} / 088.2020$

33. Tanacan A, Erol SA, Turgay B, Anuk AT, Secen EI, Yegin GF et al. The rate of SARS-CoV-2 positivity in asymptomatic pregnant women admitted to hospital for delivery: experience of a pandemic center in Turkey. Eur J Obstet Gynecol Reprod Biol. (2020) 253:31-4. doi: 10.1016/j.ejogrb.2020.07.051

34. Savirón-Cornudella R, Villalba A, Zapardiel J, Andeyro-Garcia M, Esteban LM, Pérez-López FR. Severe acute respiratory syndrome coronavirus 2 (SARSCoV-2) universal screening in gravids during labor and delivery. Eur $J$ Obstet Gynecol Reprod Biol. (2021) 256:400-4. doi: 10.1016/j.ejogrb.2020. 11.069

35. Reale SC, Lumbreras-Marquez MI, King CH, Burns SL, Fields KG, Diouf $\mathrm{K}$, et al. Patient characteristics associated with SARS-CoV-2 infection in parturients admitted for labour and delivery in Massachusetts during the spring 2020 surge: a prospective cohort study. Paediatr Perinat Epidemiol. (2021) 35:24-33. doi: 10.1111/ppe.12743

36. Pineles BL, Alamo IC, Farooq N, Green J, Blackwell SC, Sibai BM, et al. Racial-ethnic disparities and pregnancy outcomes in SARS-CoV-2 infection in a universally-tested cohort in Houston, Texas. Eur J Obstet Gynecol Reprod Biol. (2020) 254:329-30. doi: 10.1016/j.ejogrb.2020.09.012

37. Naqvi M, Burwick RM, Ozimek JA, Greene NH, Kilpatrick SJ, Wong MS. Severe acute respiratory syndrome coronavirus 2 (SARS-CoV2) universal testing experience on a Los Angeles labor and delivery unit. Obstet Gynecol. (2020) 136:235-6. doi: 10.1097/AOG.00000000000 03987

38. Mei-Dan E, Satkunaratnam A, Cahan T, Leung M, Katz K, Aviram A. Questionnaire-based vs universal PCR testing for SARS-CoV-2 in women admitted for delivery. Birth. (2020) 48:96-103. doi: 10.1111/birt.12520

39. Maru S, Patil U, Caroll-Bennett R, Baum A, Bohn-Hemmerdinge T, Ditchik A, et al. Universal screening for SARS-CoV-2 infection among pregnant women at Elmhurst Hospital Center, Queens, New York. PLoS ONE. (2020) 15:e0238409. doi: 10.1371/journal.pone.0238409

40. Hcini M, Maari F, Picone O, Carod J-F, Lambert V, Mathieu M, et al. Maternal, fetal and neonatal outcomes of large series of SARS-CoV-2 
positive pregnancies in peripartum period: a single-center prospective comparative study. Eur J Obstet Gynecol Reprod Biol. (2021) 257:118. doi: 10.1016/j.ejogrb.2020.11.068

41. Figueiredo R, Tavares S, Moucho M Ramalho C. Systematic screening for SARS-CoV-2 in pregnant women admitted for delivery in a Portuguese maternity. J Perinat Med. (2020) 48:977-80. doi: 10.1515/jpm-20200387

42. Waghmare R, Gajbhiye R, Mahajan NN, Modi D, Mukherjee S, Mahale SD. Universal screening identifies asymptomatic carriers of SARS-CoV-2 among pregnant women in India. Eur J Obstet Gynecol Reprod Biol. (2021) 256:503-5. doi: 10.1016/j.ejogrb.2020.09.030

43. Di'az-Corvillon P, Monckeberg M, Barros A, Illanes SE, Soldati A, Nien J$\mathrm{K}$, et al. Routine screening for SARS CoV-2 in unselected pregnant women at delivery. PLoS ONE. (2020) 15:e0239987. doi: 10.1371/journal.pone.02 39887

44. Blitz MJ, Rochelson B, Rausch AC, Solmonovich R, Shan W, Combs A, et al. Universal testing for coronavirus disease 2019 in pregnant women admitted for delivery: prevalence of peripartum infection and rate of asymptomatic carriers at four New York hospitals within an integrated healthcare system. Am J Obstet Gynecol MFM. (2020) 2:100169. doi: 10.1016/j.ajogmf.2020.100169

45. Hong QN, Pluye P, Fàbregues S, Bartlett G, Boardman F, Cargo M, et al. Mixed Methods Appraisal Tool (MMAT), Version. (2018). Registration of Copyright (\#1148552), Canadian Intellectual Property Office, Industry Canada.

46. The American College of Obstetrics and Gynecologists. Novel Coronavirus (2019). (COVID-19) Practice Advisory. (accessed February 6, 2021).

47. Indian Council of Medical Research. Advisory on Strategy for COVID-19 Testing in India. (Version VI, dated 4 September 2020). Available online at: https://www.mohfw.gov.in/pdf/ AdvisoryonstrategyforCOVID19TestinginIndia.pdf (accessed on December 8, 2020).

48. The Royal College of Obstetricians and Gynaecologists. Coronavirus (COVID19) Infection in Pregnancy. Information for Healthcare Professionals. (Version 12, published 14 October 2020). Available online at: https://www.rcm.org.uk/ media/4383/2020-10-14-coronavirus-covid-19-infection-in-pregnancy-v12. pdf (accessed December 8, 2020).
49. Ministry of Health Malaysia. COVID-19 Management Guidelines in Malaysia. No. 5/2020. Available online at: https://covid-19.moh.gov.my/garispanduan/garis-panduankkm/ANNEX_2e_CLINICAL_MANAGEMENT_ OF_CONFIRMED_COVID19_CASE_IN_ADULT_AND_PAEDIATRIC_ 13082021.pdf (accessed February 4, 2021).

50. Andrikopoulou M, Madden N, Wen T, Aubey JJ, Aziz A, Baptiste CD, et al. Symptoms and critical illness among obstetric patients with coronavirus disease (2019). (COVID-19) infection. Obstet Gynecol. (2020). 136:2919. doi: 10.1097/AOG.0000000000003996

51. Lokken EM, Walker CL, Delaney S, Kachikis A, Kretzer NM, Erickson A, et al. Clinical characteristics of 46 pregnant women with a severe acute respiratory syndrome coronavirus 2 infection in Washington state. Am J Obstet Gynecol. (2020) 223:911.e1-14. doi: 10.1016/j.ajog.2020.05.031

52. Duffy CR, Hart JM, Modest AM, Hacker MR, Golen T, Li Y, et al. Lymphopenia and severe acute respiratory syndrome coronavirus 2 (SARSCoV-2) infection among hospitalized obstetric patients. Obstet Gynecol. (2020). 136:229-31. doi: 10.1097/AOG.0000000000003984

Conflict of Interest: The authors declare that the research was conducted in the absence of any commercial or financial relationships that could be construed as a potential conflict of interest.

Publisher's Note: All claims expressed in this article are solely those of the authors and do not necessarily represent those of their affiliated organizations, or those of the publisher, the editors and the reviewers. Any product that may be evaluated in this article, or claim that may be made by its manufacturer, is not guaranteed or endorsed by the publisher.

Copyright (c) 2022 Hashim, Mahdy, Abdul Rahman, Kalok and Sutan. This is an open-access article distributed under the terms of the Creative Commons Attribution License (CC BY). The use, distribution or reproduction in other forums is permitted, provided the original author(s) and the copyright owner(s) are credited and that the original publication in this journal is cited, in accordance with accepted academic practice. No use, distribution or reproduction is permitted which does not comply with these terms. 